\title{
Lean Design of Assembly Line for Promote Continuous Improvement
}

\author{
A.D. Awasare ${ }^{1}$, P.S. Jadhav ${ }^{2}$, D.S. Chinchkar ${ }^{3}$ \\ Assistant Professor, Mechanical Engg, Dept, AGTI's DACOE Karad, India ${ }^{1,3}$ \\ Assistant Professor, Mechanical Engg, Dept, RIT Rajaramnagar, Islampur, India ${ }^{2}$
}

\begin{abstract}
All of the assembly line layout problems are composed with space of the layout as well as regarding with the flow of the material. The goal of the assembly line layout problem is to meet the minimum requirements of the processing unit while saving space and optimize the degree of logistics costs and non-logistics as possible. It has identified several wastes in the internal material supply chain to latest assembly layout and suspect that there are more to be found. In upcoming assembly line layout the company wishes to reduce or eliminate these wastes in the work region.
\end{abstract}

Keywords: Line layout, Logistics, Optimize.

\section{INTRODUCTION}

What was worked out at Ford was the practice of moving the work from one worker to another until it became a complete unit, then arranging the flow of these units at the right time and the right place to a moving final assembly line from which came a finished product. Regardless of earlier uses of some of these principles, the direct line of succession of mass production and its intensification into automation stems directly from what we worked out at Ford Motor Company between 1908 and 1913. Henry Ford is generally regarded as the father of mass production. He was not. He was the sponsor of it." This approach seems particularly well suited assembly line layout to synchronous flow of facilities. The general purpose of assembly line layout planning focuses on equipment's selection, processing alternatives, assignment restrictions etc. To balance assembly line various methods are available including employ trained workers, utilization of high performance machine, applying material handling principles, designing non-adjacent plant layout etc. Yet, there is another method which is the most welcoming among these methods; it is productivity improvement by simulation method.

\section{ASSEMBLY PROCESS}

Assembly involves the joining together of two or more separate parts to form a new entity (Assembly or subassembly). The processes used to accomplish the assembly of the components can be divided into three major categories.

1. Mechanical Fastening -Mechanical action to hold components together.

- Threaded fasteners - screws, bolts, nuts etc.

- Rivets, crimping and other methods

- Press fits
- Snap fits -temporary interface of the two parts C-ring.

- Sewing and stitching -for soft, thin material.

2. Joining Methods -welding, brazing and soldering

3. Adhesive Bonding -thermoplastic, thermosetting (chemical reaction)

\section{TERMINOLOGY}

- Minimum Rational Work Element

Minimum rational work element is the smallest practical indivisible tasks into which the job can be divided. These work elements cannot be subdivided further.Work carrier Or Base part in Components added at each station.

Example: drilling a hole, screw and nut etc.

$T_{e j}$ : where $j$ is used to identify the element out of the ' $n$ ' elements that make up the total work.

- Total Work Content

Total work, $\mathrm{T}_{\mathrm{wc}}$, content is the aggregate of all the work elements to be done on the line.

$$
\mathrm{T}_{\mathrm{wc}}=\sum \mathrm{T}_{\mathrm{ej}}
$$

- Workstation Process Time

Work is preformed either manually or by some automatic device. The work performed at station consists of one or more of the individual work elements.

$$
\sum \mathrm{T}_{\mathrm{si}}=\sum \mathrm{T}_{\mathrm{ej}}
$$

- Cycle Time

Cycle time, $T_{c}$, is the ideal or theoretical cycle time of the flow line, which is the time interval between parts coming off the line.

When consider efficiency, E, the ideal cycle time must be reduce. 


\section{IAR JSET}

International Advanced Research Journal in Science, Engineering and Technology

National Conference on Design, Manufacturing, Energy \& Thermal Engineering (NCDMETE-2017) AGTI's Dr. Daulatrao Aher College Engineering, Vidyanagar Extension, Karad

Vol. 4, Special Issue 1, January 2017

Where $\mathrm{Rp}$ is production rate.

$$
\mathrm{Tc} \leq \frac{E}{R p}
$$

*At efficiencies less than $100 \%$ the ideal cycle time must be reduced (or ideal production rate must be increased).

* The minimum possible value of Tc is established by the bottleneck station, the one with the largest value of Ts.

$$
\begin{gathered}
\mathrm{Tc} \geq \mathrm{Ts}_{\mathrm{i}} \max \\
\mathrm{Tc} \geq \mathrm{T}_{\mathrm{ej}}
\end{gathered}
$$

- Precedence Constraints

Technological sequencing requirements, the order in which the work elements can be accomplished is limited.

\section{- Precedence Diagram}

A graphical representation of the sequence of work elements is defined by the precedence constraints.

- Balance Delay (Balancing Loss)

Balance delay is a measure of the line efficiency which results from idle time due to imperfect allocation of work among station

$$
\mathrm{D}=\frac{n T c-T w c}{n \cdot T c}
$$

\section{EXISTING ASSEMBLY LINE LAYOUT}

The line is to be equipped to assemble compressor starting from the main components. The assembly operations have been subdivided in different workstations are shown in layout all the main components that opportunely assembled forms the final product at the final station as shown in fig. 1 existing U-line layouts as shown have been utilized for production lines in place of the traditional straight- line configuration due to the use of just-in-time principles. The shape of U-line improves visibility and allows the construction of stations containing tasks on both sides of the line. This arrangement, combined with cross-trained operators, provides greater flexibility in station construction than is available on a comparable straight production line.

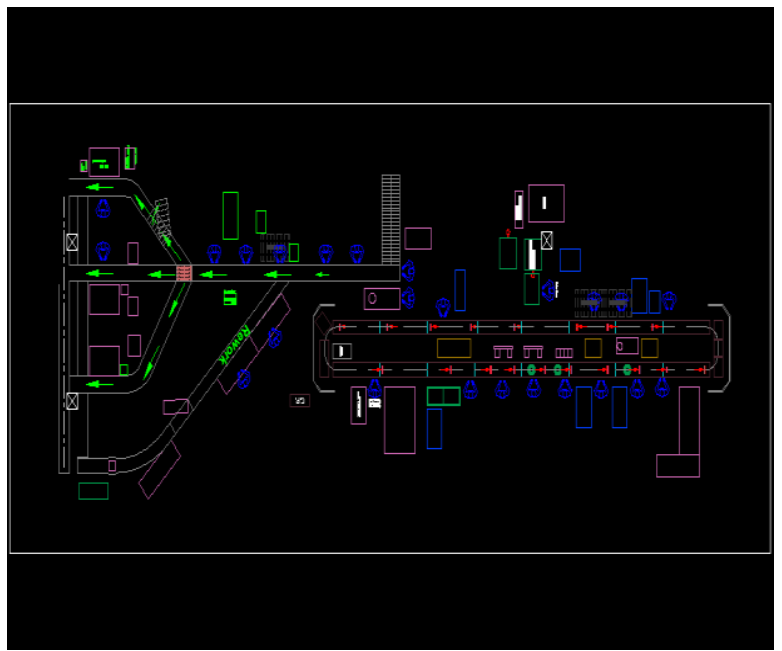

Fig.1 Existing Assembly Line Layout
However, there are many areas in U-line assembly line balancing which require further research that is necessary to find more flexible solution approaches which provide a good compromise with respect to finding good feasible solutions early and saving enumeration effort.

\section{LEAN ASSEMBLY LINE LAYOUT}

Manufacturing factory floor simulations are invaluable tools in the implementation of lean manufacturing. Many manufacturers will not make a change to the process before a simulation is performed to determine the impact of the change. Simulation can be considered as inexpensive insurance against costly mistakes. A high volume manufacture was evaluating several alternative layouts for their proposed assembly facility. After an initial review, two alternatives were selected upon which to apply their limited simulation resources.

Existing was a more traditional layout, while Lean Layout as shown in fig. 2 applied many lean principles. The lean alternative incorporated a kanban replenishment system, value stream mapping find the less work-in process, compressed layout, visual management techniques standardized work and quicker change over methods. The two alternatives were compared on the metrics of throughput, work-in process, square feet required and cost. The lean alternative showed an increase in throughput, lower working process, less square feet required and a lower cost.

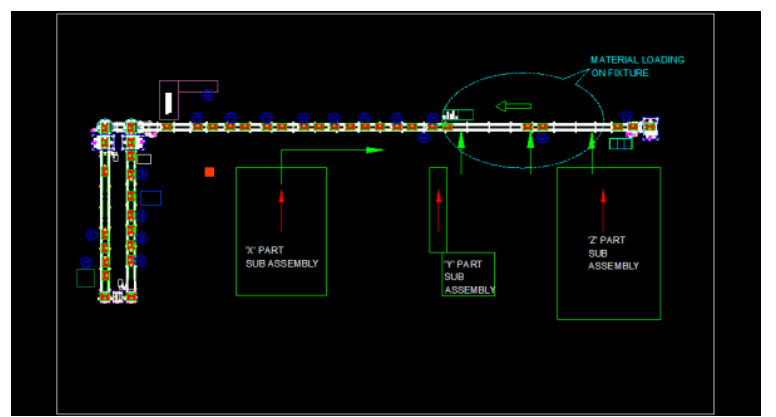

Fig.2 Lean Assembly Line Layout

\section{MATHEMATICAL CALCULATION}

1) Throughput Time $=\mathrm{T}=\mathrm{ti}=$ Part $\mathrm{A}+\ldots . . \mathrm{t} 1+\ldots \mathrm{t} 24=$ $9.63+14.4+\ldots .+51.45=631.06 \mathrm{sec}=10.51$. Min

2) Assume one shift operation $=8$ hours $=(60) \times(8)=$ 480 minutes $=28800 \mathrm{sec}$

3) Time allowed for breaks $=50$ minutes $=3000 \mathrm{sec}$

4) Total productive time $=\mathrm{P}=430$ minutes $/$ day $=25800$ sec

5) Customer Demand Per Shift $=1073$ Compressors

6) Down time $=20 \mathrm{~min}=1200 \mathrm{Sec}$

7) Cycle time $=($ Consider highest output per shift $)$

$$
\begin{aligned}
& =\frac{24600}{1000} \\
& =24.6 \mathrm{Sec} / \text { unit }
\end{aligned}
$$


IARJSET

International Advanced Research Journal in Science, Engineering and Technology

National Conference on Design, Manufacturing, Energy \& Thermal Engineering (NCDMETE-2017)

AGTI's Dr. Daulatrao Aher College Engineering, Vidyanagar Extension, Karad

Vol. 4, Special Issue 1, January 2017

8) Total idle time $=\quad N \times C T-\sum t$

$$
=27 \times 24.6-(631.06) \ldots
$$

$($ Consider actual no. of workstation $)=16.94 \mathrm{sec}$

9) Balance delay $=1$ - (Assembly line efficiency)

$$
\begin{gathered}
=1-(0.950) \\
=0.05
\end{gathered}
$$

\section{TIME COMPARISON OF ASSEMBLY LAYOUT}

Table I. Time Comparison of Layouts

\begin{tabular}{|l|c|c|c|}
\hline \multirow{2}{*}{ Assembly } & \multicolumn{3}{|c|}{ Operation in sec } \\
\cline { 2 - 4 } & Previous & Assembly & Lean \\
\hline Assembly 01 & 13.95 & Part load & 2.3 \\
\hline Assembly 02 & 12.96 & Part load & 2.5 \\
\hline Assembly 03 & 20.2 & Part load & 1.5 \\
\hline Assembly 04 & 13.77 & Part load & 1.3 \\
\hline Assembly 05 & 18.02 & Part load & 1.5 \\
\hline Assembly 06 & 14.27 & Part load & 1.5 \\
\hline Assembly 07 & 6.6 & Part load & 1.5 \\
\hline Assembly 08 & 15.80 & 1 & 11.32 \\
\hline Assembly 09 & 4.05 & 2 & 10.03 \\
\hline Assembly 10 & 6.21 & 3 & 16.4 \\
\hline Assembly 11 & 12.69 & 4 & 9.03 \\
\hline Assembly 12 & 1.61 & 5 & 9.62 \\
\hline Assembly 13 & 15.39 & 6 & 9.15 \\
\hline Assembly 14 & 13.50 & 7 & 18.41 \\
\hline Assembly 15 & 5.67 & 8 & 13.70 \\
\hline Assembly 16 & 15.39 & 9 & 4.32 \\
\hline Assembly 17 & 21.12 & 10 & 9.43 \\
\hline Assembly 18 & 4.05 & 11 & 9.18 \\
\hline Assembly 19 & 13.65 & 12 & 1.88 \\
\hline Assembly 20 & 17.01 & 13 & 16.32 \\
\hline Assembly 21 & 21.18 & 14 & 13.45 \\
\hline Assembly 22 & 13.64 & 15 & 5.66 \\
\hline Assembly 23 & 7.22 & 16 & 13.77 \\
\hline Assembly 24 & 7.39 & 17 & 18.43 \\
\hline Assembly 25 & 4.32 & 18 & 4.05 \\
\hline Assembly 26 & 28.75 & 19 & 13.35 \\
\hline Assembly 27 & 20.55 & 20 & 16.51 \\
\hline Assembly 28 & 14.33 & 21 & 21.32 \\
\hline Assembly 29 & 4.32 & 22 & 21.69 \\
\hline Assembly 30 & 2.71 & 23 & 16.15 \\
\hline Assembly 31 & 19.44 & 24 & 16.19 \\
\hline Assembly 32 & 51.45 & 25 & 35.50 \\
\hline Assembly 33 & 51.45 & 26 & 35.50 \\
\hline Total & $\mathbf{4 6 6 . 7 3}$ & Total & $\mathbf{3 8 2 . 4 6}$ \\
\hline
\end{tabular}

The benefits of implementing Lean can be broken down into three broad categories; Operational, Administrative, and Strategic Improvements. Even to this day, most organizations that implement lean do so for the operational improvements, primarily because of the perception that lean only applies to the operations side of the business. However, from experienced, Lean's administrative and strategic benefits are equally impressive.

Some of Lean's benefits are summarized below. Results of the experiment confirm that U-shaped and straight line layouts can improve labour productivity modestly on average, but surprisingly, the results also indicate that the majority of problem instances experience no improvement in labour productivity.

This finding is critically important, because it brings to light that fact that managers cannot blindly convert to a Ushaped and straight line layout and expect to attain cost savings by improving labour efficiency. However, when an improvement occurred, the effect is quite large, yielding an average improvement in labour productivity that exceeds $10 \%$. 


\section{REFERENCES}

[1] Erdal Erel, Hadi Gokcen, "Shortest-route formulation of mixedmodel assembly line balancing problem", European Journal of Operational Research 116 (1999) 194-204.

[2] D. Roy, D. Khan, "Assembly line balancing to minimize balancing loss and system loss", J. Ind. Eng. Int., 6 (11), 1-5, Spring 2010 ISSN: 1735-5702 @ IAU, South Tehran Branch P.

[3] Joaquin Bautista, Raul Suarez, Manuel Mateo, Ramon Company's, "Local Search Heuristics for the Assembly Line Balancing Problem with Incompatibilities between Tasks", Institute d' Control de Sistemes Industrials journals.

[4] Adil Baykasoglu and Turkay Dereli, "Simple and U-type assembly line balancing by Using an ant colony based algorithms", Mathematical and Computational Applications, Vol. 14, No. 1, pp. 1-12, 2009.@ Association for Scientific Research.

[5] S.J. Hu , J. Ko , L. Weyand, H.A. E Maraghy , T.K. Lien , Y. Koren , H. Bley ,G. Chryssolouris , N. Nasr , M. Shpitalni , "Assembly system design and operations for product variety", CIRP Annals - Manufacturing Technology 60 (2011) 715-733.

[6] Alena Otto, Armin Scholl "Incorporating ergonomic risks into assembly line balancing ", European Journal of operation Research 212 (2011) 277-286.

[7] Telsang Mertand T, "Industrial Engineering and Production Management" (S.Chand, 2011 2012).

[8] Ashwathappa, Bhat "Production and Operation management" (Himalaya Publishing). 